\title{
Influence of doxorubicin on apoptosis and oxidative stress in breast cancer cell lines
}

\author{
NESSTOR PILCO-FERRETO ${ }^{1}$ and GLORIA M. CALAF ${ }^{1,2}$ \\ ${ }^{1}$ Institute for Advanced Research, University of Tarapacá, 8097877 Arica, Chile; \\ ${ }^{2}$ Center for Radiological Research, Columbia University Medical Center, New York, NY 10032, USA
}

Received January 15, 2016; Accepted February 20, 2016

DOI: 10.3892/ijo.2016.3558

\begin{abstract}
Breast cancer is one of the leading causes of mortality among women worldwide due to aggressive behavior, early metastasis, resistance to existing chemotherapeutic agent and high mortality rate. Doxorubicin (Dox) is a powerful antitumoral drug. It is one of the most active agents for treatment of breast cancer. The aim of the present study was to evaluate the influence of Dox in apoptosis and oxidative stress in the breast cancer cell lines MCF-10F, MCF-7 and MDA-MB231. These studies showed that Dox decreased anti-apoptotic Bcl-2 protein expression and affected oxidative stress by increasing hydrogen peroxide production and simultaneously decreasing NF- $\kappa \mathrm{B}$ gene and protein expression in MCF-7, a tumorigenic triple-positive cell line. Results also indicated that Dox induced apoptosis by upregulating Bax, caspase- 8 and caspase- 3 and downregulation of $\mathrm{Bcl}-2$ protein expression. On the contrary, ROS damage decreased by increasing SOD2 gene and protein expression and hydrogen peroxide production with parallel $\mathrm{NF}-\kappa \mathrm{B}$ protein expression decrease in MDA-MB-231, a tumorigenic triple-negative breast cancer cell line. It can be concluded that Dox activated apoptosis by inducing proteolytic processing of Bcl-2 family, caspases and simultaneously decreased oxidative stress by influencing ROS damage in MCF-7 and MDA-MB-231 cell lines.
\end{abstract}

\section{Introduction}

Breast cancer is one of the leading causes of mortality among women in world due to various factors such as aggressive invasion, early metastasis, resistance to existing chemotherapeutic drugs and high mortality (1). Doxorubicin (Dox) is an anthracycline of wide spectrum and an essential component of many treatment regimens for tumors and it is broadly considered the most active agent for breast cancer

Correspondence to: Dr Gloria M. Calaf, Institute for Advanced Research, University of Tarapacá, Calle Antofagasta \#1520, 8097877 Arica, Chile

E-mail: gmc24@cumc.columbia.edu

Key words: apoptosis, reactive oxygen species, superoxide dismutase 2, doxorubicin therapy (2). Dox shows a variety of molecular mechanisms at cellular level to explain its role as intercalation between two nitric bases of double DNA helix, generation of free radicals leading to rupture of DNA strands, inhibition of the respiratory chain enzymes in mitochondria, membrane lipid oxidation, interference with DNA unwinding and helicase activity, and induction of apoptosis in response to topoisomerase II inhibition (3).

Apoptosis is a process of cell death in multicellular organism and its regulation is important for normal growth, homeostasis, development and cancer treatment. Alterations of normal induction to apoptosis can cause growth of abnormal cells, uncontrolled cell division and accumulation of mutations (4). Therefore, regulation of apoptosis plays an important role in the treatment of cancer (5).

The group of B-cell lymphoma-2 protein ( $\mathrm{Bcl}-2)$ is a key regulator in the molecular mechanisms of apoptosis (6). This family includes protein function as Bcl-2-associated protein $\mathrm{X}$ (Bax) promoter that induces and accelerates cell death when associated with the formation of Bax/Bax homodimer. Whereas, Bcl-2 and B-cell lymphoma extra-large (Bcl-xL) antiapoptotic protein expression are repressed by Bax through the formation of Bcl-2/Bax or Bcl-xL/Bax heterodimers (7-9). Complex networks of interactions between Bcl-2 family members both cytosolic and mitochondrial determine the fate of the cell for death or survival (10).

Caspase family is a group of cysteine proteases that activate apoptosis execution in two main pathways. The first pathway is extrinsic death receptor-dependent and the second pathway depends on mitochondria. Induction of both apoptotic pathway are associated with the activation of caspases (11). Caspase- 8 is the main death receptor signaling caspase (12). Effector caspase-3 is a frequently activated death protease that catalyzes the specific cleavage of many key cellular proteins. Caspase- 3 activation pathways have been identified to be both dependent and non-dependent of mitochondrial cytochrome $c$ release and caspase-9 function (13). Caspase-3 is required for some typical hallmarks of apoptosis and it is indispensable for apoptotic chromatin condensation and DNA fragmentation. Thus, caspase- 3 is essential for processes associated with cell rupture and the formation of apoptotic bodies (14). Caspase- 8 is an initiator caspase and activates apoptosis when death receptors are stimulated but it is also required by other apoptotic stimuli (15). 
It has been proposed that production of ROS (reactive oxygen species) leads to an imbalance between ROS generation and degradation by cellular antioxidant mechanisms, this deregulation is called oxidative stress $(16,17)$. High levels of ROS participate in genomic instability and lead to aggressiveness and progression of carcinogenesis. This process is accompanied by the activation of various gene and transcription factors in cancer cells (18). Superoxide radical is generated in many cellular processes mainly by the electron transport chain into mitochondria (19).

Dox causes oxidative damage in tumor cells and it is based on redox cycling accompanied by the release of iron from cells. The drug-iron complex catalyzes $\mathrm{O}_{2}$ and $\mathrm{H}_{2} \mathrm{O}_{2}$ conversion into more potent radicals. Oxidative damage mechanism has been considered an important antitumoral mechanism in cancer cells (3).

Superoxide dismutase 2 (SOD2) is a protein of the mitochondrial matrix that catalyzes the formation of superoxide radical into hydrogen peroxide (20). Overexpression of SOD2 results in a marked suppression of cell growth (21). SOD2 and hydrogen peroxide levels are higher in MDA-MB-231 than in MCF-7 cell lines (22).

Nuclear factor kappa-B (NF-kB) is a transcription factor that regulates the expression of hundreds of genes that are involved in regulating cell growth, differentiation, development and apoptosis pathway in the cytoplasm $(23,24)$. Dox can activate the ubiquitin proteasome system that regulates the $\mathrm{NF}-\kappa \mathrm{B}$ transcription factor and overactivation of NF- $\mathrm{\kappa B}$ leads to an increase of many cell functions that have been shown in several tumor types (25).

The aim of the present study was to evaluate the influence of Dox on apoptosis and oxidative stress in three breast cancer cell lines the MCF-10F, which is non-tumorigenic not expressing estrogen receptor (ER), progesterone receptor (PR) or human epidermal growth factor receptor 2 (HER2); The MCF-7 cell line, a tumorigenic triple-positive expressing ER, PR and HER2; and MDA-MB-231, a tumorigenic triplenegative breast cancer cell line.

\section{Materials and methods}

Cell lines and culture conditions. Three human breast cell lines were used for all the experiments, the control cell line MCF-10F, a luminal-like (estrogen receptor positive) MCF-7 and a triple-negative breast cancer cell line MDA-MB-231. MCF-10F cell line (ATCC, Manassas, VA, USA), a spontaneously immortalized breast epithelial cell line, retains all the characteristics of normal epithelium in vitro including anchorage-dependence, non-invasiveness and non-tumorigenicity in nude mice. MCF-10F cell line was grown in DMEM/F-12 (1:1) medium supplemented with antibiotics [100 U/ml penicillin, $100 \mu \mathrm{g} / \mathrm{ml}$ streptomycin, $2.5 \mu \mathrm{g} / \mathrm{ml}$ amphotericin B (all from Life Technologies, Grand Island, NY, USA)] and $10 \mu \mathrm{g} / \mathrm{ml}$ and $5 \%$ equine serum (Biofluids, Rockville, MD, USA), $0.5 \mu \mathrm{g} / \mathrm{ml}$ hydrocortisone (Sigma, St. Louis, MO, USA) and $0.02 \mu \mathrm{g} / \mathrm{ml}$ epidermal growth factor (Collaborative Research, Bedford, MA, USA) were added. The cell line MCF-7 was cultivated in the Dulbecco's modified Eagle's medium (Sigma-Aldrich ChemieGmbH, Munich, Germany) supplemented with $10 \%$ fetal calf serum
(FCS; Sigma-Aldrich) at $37^{\circ} \mathrm{C}$ and saturated air with $5 \% \mathrm{CO}_{2}$. Human triple-negative breast cancer cells MDA-MB-231 were purchased from the American Type Culture Collection and were maintained in DMEM medium supplemented with $10 \%$ FBS, $100 \mathrm{IU} / \mathrm{ml}$ penicillin, and $100 \mathrm{mg} / \mathrm{ml}$ streptomycin and incubated at $37^{\circ} \mathrm{C}$ with $\mathrm{CO}_{2}$.

Drug treatment. Dox and dimethyl sulfoxide (DMSO) were purchased from Sigma-Aldrich. Each Dox concentration was added when cells reached $70 \%$ confluence and cultured for 24 and $48 \mathrm{~h}$. Concentrations of 1, 2, 4 and $8 \mu \mathrm{M}$ were prepared with DMSO 0.05\%.

Cell viability. Cell viability of MCF-10F, MCF-7 and MDA-MB-231 cell lines was determined by using 3-(4,5dimethylthiazol-2-yl)-2,5-diphenyl-tetrazolium bromide (MTT) which evaluated the percentage of viable cells. Cells were seeded into 24-well plate with concentration of $5 \times 10^{4}$ cells/well and the following concentrations of Dox were tested $0,1,2,4$ and $8 \mu \mathrm{M}$. Four wells remained untreated as control. MTT assay was carried out for 24 and $48 \mathrm{~h}$ after treatments. Mixing solution was prepared using $2 \mathrm{mg}$ of MTT (Sigma-Aldrich) powder in $1 \mathrm{ml}$ PBS. The culture medium was changed with $150 \mu \mathrm{l}$ fresh media plus $50 \mu \mathrm{l}$ MTT reagent ( $2 \mathrm{mg} / \mathrm{ml}$ in PBS); the cell-free wells were considered as blank controls. Cells were incubated at $37^{\circ} \mathrm{C}$ with $\mathrm{CO}_{2}$ at $5 \%$ and a humidified atmosphere for $4 \mathrm{~h}$. Then, the MTT solution was removed and $200 \mu \mathrm{l}$ of DMSO were added to each well. The plate was maintained for $30 \mathrm{~min}$ at $37^{\circ} \mathrm{C}$ and then the OD (optical density) of the wells was determined at $550 \mathrm{~nm}$ through a spectrophotometric microplate reader (BioTek Instruments, Inc., Winooski, VT, USA).

Western blot analysis. Cells were lysated with $0.5 \mathrm{ml}$ lysis buffer (pH 7.2) [Tris-Base $(50 \mathrm{mM})$, EDTA $(1 \mathrm{mM}), \mathrm{NaCl}$ $(100 \mathrm{mM})$, PMSF $(1 \mathrm{mM})$, and centrifuged at $13,400 \mathrm{rpm}$ for $10 \mathrm{~min}]$. Cellular proteins from the supernatant were dissolved in SDS-PAGE sample solution [60 mM Tris, $\mathrm{pH}$ 6.5, $10 \%(\mathrm{w} / \mathrm{v})$ glycerol, $5 \%(\mathrm{w} / \mathrm{v}) \beta$-mercaptoethanol, $20 \%(\mathrm{w} / \mathrm{v})$ SDS, and $0.025 \%(\mathrm{w} / \mathrm{v})$ bromophenol blue] and denatured by boiling $\left(100^{\circ} \mathrm{C}\right.$ for $\left.5 \mathrm{~min}\right)$. The total amount of protein used was $50 \mu \mathrm{g}$ per lane for Bax (sc-493), Bcl-2 (sc-7382), caspase-8 (sc-56070), caspase-3 (sc-7148), SOD2 (sc-18503) and NF-кB (sc-7386) with standard protein markers from Bio-Rad Laboratories (Hercules, CA, USA). After fractionation by SDS-PAGE on gels $(5 \times 8 \mathrm{~cm})$, proteins were electroblotted onto polyvinylidene difluoride membrane using a blotting apparatus (Bio-Rad Laboratories). Pre-stained SDS-PAGE (standards) blots were blocked for $1 \mathrm{~h}$ in 5\% defatted dry milk-TBS- $0.5 \%$ Tween and then incubated overnight at room temperature with corresponding primary antibodies. The following primary antibodies were used Bax (B-9) 1:4,000; Bcl-2 (N-19) 1:5,000; caspase-8 (8CSP03) 1:200; caspase-3 (H-277) 1:200; NF- $\mathrm{KB}$ (4D1) 1:200; SOD2 (A-2) 1:200; $\beta$-actin (C-4) 1:5,000. Secondary antibodies used were goat anti-mouse (Sc-2005) 1:5,000 and goat anti-rabbit (Sc-2030) 1:5,000. All primary and secondary antibodies were obtained from Santa Cruz Biotechnology (Santa Cruz, CA, USA). Film was analyzed with Adobe Photoshop for Windows 7 software to obtain the relative grade of luminescence to calculate the fold expression. 
Table I. Primers of genes selected for differential display reverse transcriptase-PCR (DDRT-PCR) analysis.

\begin{tabular}{ll}
\hline Gene name & \multicolumn{1}{c}{ PCR primer sequences $^{\mathrm{a}}$} \\
\hline$\beta$-actin & F: TGC CGA CAG GAT GCA GAA G \\
& R: GCC GAT CCA CAC GGA GTA CT \\
Bax & F: GCG AGT GTC TCA AGC GCA TC \\
& R: CCA GTT GAA GTT GCC GTC AGA A \\
Bcl- $x$ L & F: CTG AAT CGG AGA TGG AGA CC \\
& R: TGG GAT GTC AGG TCA CTG AA \\
Caspase-8 & F: CAT CCA GTC ACT TTG CCA GA \\
& R: GCA TCT GTT TCC CCA TGT TT \\
Caspase-9 & F: CCA GAG ATT GCG AAA CCA GAG G \\
& R: GAG CAC CGA CAT CAC CAA ATT C \\
Caspase-3 & F: CAG AAC TGG ACT GTG GCA TTG \\
& R: GCT TGT CGG CAT ACT GTT TCA \\
SOD2 & F: CCC TGG AAC CTC ACA TCA AC \\
& R: CCT TGC AGT GGA TCC TGA TT \\
NF- $\kappa$ (p65) & F: ATC TGC CGA GTG AAC CGA AAC T \\
& R: CCA GCC TGG TCC CGT GAA A \\
\hline
\end{tabular}

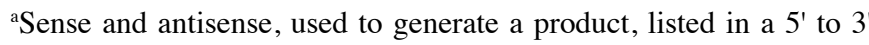
orientation.

Differential display reverse transcriptase-PCR (DDRT-PCR) assessment. Total RNA was isolated using TRIzol reagent (Invitrogen Corp., Long Island, NY, USA). The purified RNA sample was first measured by a spectrophotometer (the ratio of absorbance reading at $260 / 280 \mathrm{~nm}>1.8$ ) and then electrophoresed on $1 \%(\mathrm{w} / \mathrm{v})$ agarose gel to check its quality and purity. RNA $(2 \mu \mathrm{g})$ was used for reverse transcriptase-polymerase chain reaction (DDRT-PCR). The first-strand cDNA was synthesized with primer oligo-(dT) to hybridize to 3'-poly-(A) tails. To confirm their similar expression in all samples human $\beta$-actin was used as a control amplifier set. Table I shows the primers of genes selected for DDRT-PCR analyses, including the symbol and type of primers of Bax, Bcl-xL, caspase- 8 , caspase-9, caspase-3, SOD2, NF- $\mathrm{KB}$ and $\beta$-actin. All primers were obtained from Integrated DNA Technologies (Coralville, IA, USA). To confirm the differential gene expression $2 \mu \mathrm{l}$ of cDNA and a varied number of PCR cycles $(20,25$ and 30$)$ were used to generate gene-specific probes. A linear increase was observed in product generation in all cases (log-phase). Then, $2 \mu \mathrm{l}$ of cDNA and 30 cycles for Bax, Bcl-xL and NF-kB; and 25 cycles for $\beta$-actin for PCR were used. Table II shows the protocol of DDRT-PCR analyses, PCR step, temperature and time. In each PCR initial cycle of $94^{\circ} \mathrm{C}$ for 10 min was necessary to activate Taq polymerase. Final cycle of $72^{\circ} \mathrm{C}$ for 5 min was utilized to complete the amplicon produced. The PCR product was run on a $2 \%(w / v)$ agarose gel with ethidium bromide $5 \mathrm{mg} / \mathrm{ml}$. Differentially expressed gene-specific DNA bands were then photographed and analyzed with Adobe Photoshop software to obtain the relative grade of luminescence to calculate the fold-change of expression.
Table II. Protocol of differential display reverse transcriptasePCR (DDRT-PCR).

\begin{tabular}{lccc} 
Gene symbol & Cycles (no.) & PCR step & Temperature/time \\
\hline$\beta$-actin & 25 & Annealing & $58^{\circ} \mathrm{C} / 30 \mathrm{sec}$ \\
Bax & 30 & Annealing & $58^{\circ} \mathrm{C} / 30 \mathrm{sec}$ \\
Bcl- $x$ L & 25 & Annealing & $55^{\circ} \mathrm{C} 30 \mathrm{sec}$ \\
Caspase- 8 & 25 & Annealing & $56^{\circ} \mathrm{C} / 30 \mathrm{sec}$ \\
Caspase-9 & 30 & Annealing & $58^{\circ} \mathrm{C} / 30 \mathrm{sec}$ \\
Caspase-3 & 30 & Annealing & $58^{\circ} \mathrm{C} / 30 \mathrm{sec}$ \\
SOD2 & 25 & Annealing & $57^{\circ} \mathrm{C} / 30 \mathrm{sec}$ \\
NF- $\kappa B$ & 30 & Annealing & $58^{\circ} \mathrm{C} / 30 \mathrm{sec}$
\end{tabular}

Every PCR initial cycle of $94^{\circ} \mathrm{C}$ for 10 min was necessary to activate Taq polymerase, $94^{\circ} \mathrm{C}$ for $30 \mathrm{sec}$ for a DNA denaturation, $72 \mathrm{C}$ for 30 sec for extension step and a final cycle of $72^{\circ} \mathrm{C}$ for 5 min was utilized to complete the amplicon produced.

Measurement of $\mathrm{H}_{2} \mathrm{O}_{2}$ concentration. To determine the hydrogen peroxide level the Amplex Red Hydrogen Peroxide/ Peroxidase assay kit purchased from Molecular Probes (Eugene, OR, USA) was used. The protocol was according to the manufacturer's procedure. HRP stock solution $(10 \mathrm{U} / \mathrm{ml})$ was diluted $(0-2 \mathrm{mU} / \mathrm{ml})$ for the standard curve. A volume of $50 \mu \mathrm{l}$ was used for each reaction of individual wells of a microplate. The microplate with reactions was incubated at room temperature for $30 \mathrm{~min}$ and protected from light. The absorbance was measured in a microplate reader at $560 \mathrm{~nm}$. The background was corrected for each point subtracting the value derived from the no-HRP control.

Statistical analysis. Results of the cell growth assay were presented as mean \pm standard error (SE) in three independent experiments and the comparison between treated and control groups was carried out by ANOVA and Dunnett's test. $\mathrm{P}<0.05$, $\mathrm{P}<0.01$ and $\mathrm{P}<0.001$ were considered significant. Analysis of gene and protein expression was performed using the Student's t-test to compare control with treatment. $\mathrm{IC}_{50}$ dose at $50 \%$ was calculated by a non-linear regression curve using GraphPad Prism 5.0 for Windows (GraphPad Software, Inc., San Diego, CA, USA).

\section{Results}

Cell viability and $I C_{50}$ values. To study viability induced by Dox the breast cancer cell lines MCF-10F, MCF-7 and MDA-MB231 were used. They were treated with increasing doses of Dox for 24 and $48 \mathrm{~h}$ and the metabolic activity was quantified by MTT assay. Fig. 1 shows that the $\mathrm{IC}_{50}$ (drug concentration required to inhibit cell growth by $50 \%$ ) was determined by different concentrations $(1,2,4$ and $8 \mu \mathrm{M})$ in each breast cancer cell line for 24 and $48 \mathrm{~h}$. These values indicated that $\mathrm{IC}_{50}$ was $1 \mu \mathrm{M}$ for both MCF-10F and MDA-MB-231 cell lines and for MCF-7 cell line it was $4 \mu \mathrm{M}$. This assay showed that increased concentration of Dox decreased the viability of all three cell lines in a time- and dose-dependent manner for $48 \mathrm{~h}$. 

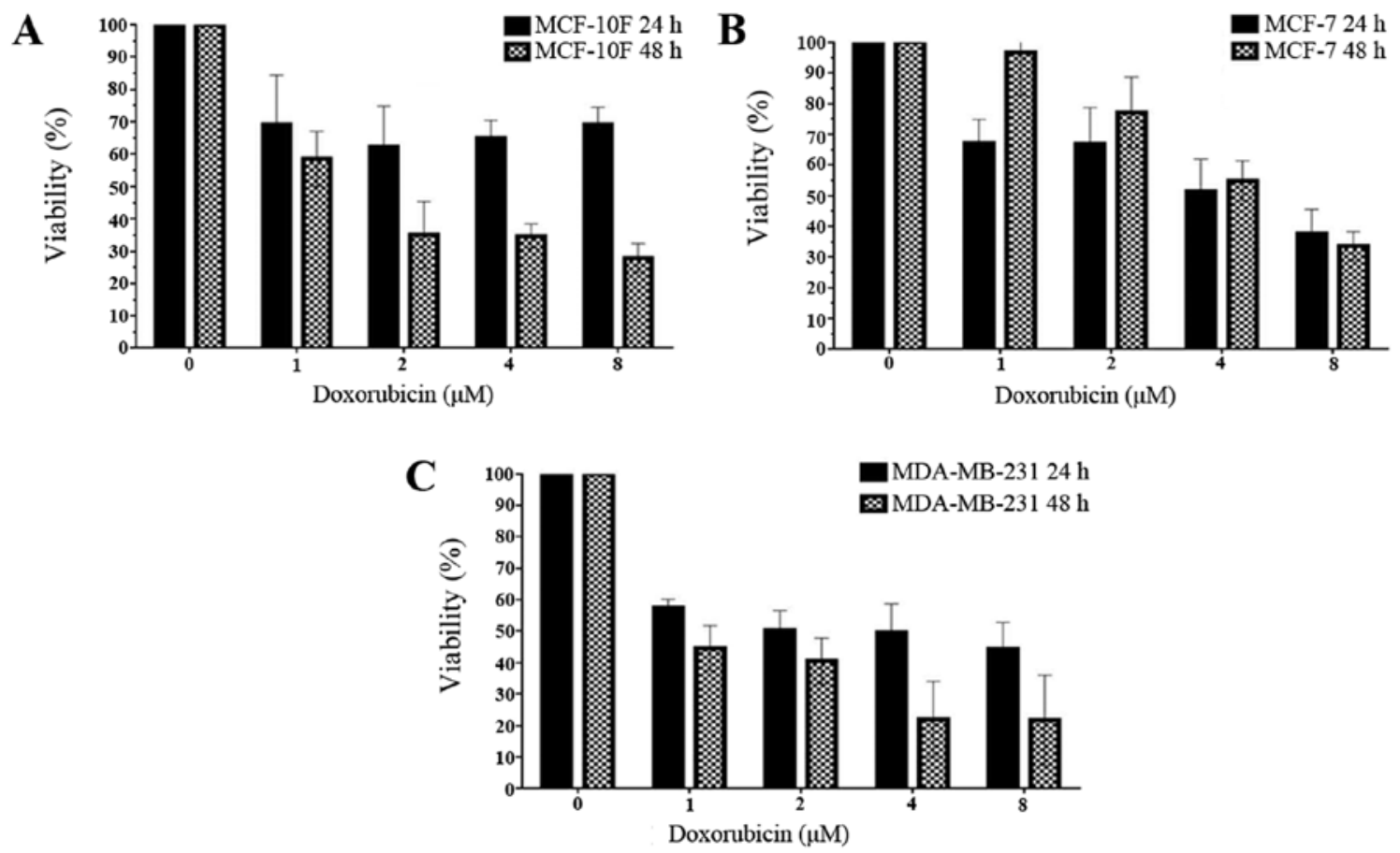

Figure 1. Cell viability in three breast cancer cell lines. Effect of Dox in cell viability was determined by using the MTT assay and an automated cell counter. Cell lines were treated with different doses of Dox (from 0 to $8 \mu \mathrm{M}$ ) and incubated for 24 and $48 \mathrm{~h}$. (A) MCF-10F cell line (B) MCF-7 cell line, (C) MDA-MB-231 cell line. Bars represent the mean \pm SE of three independent experiments.
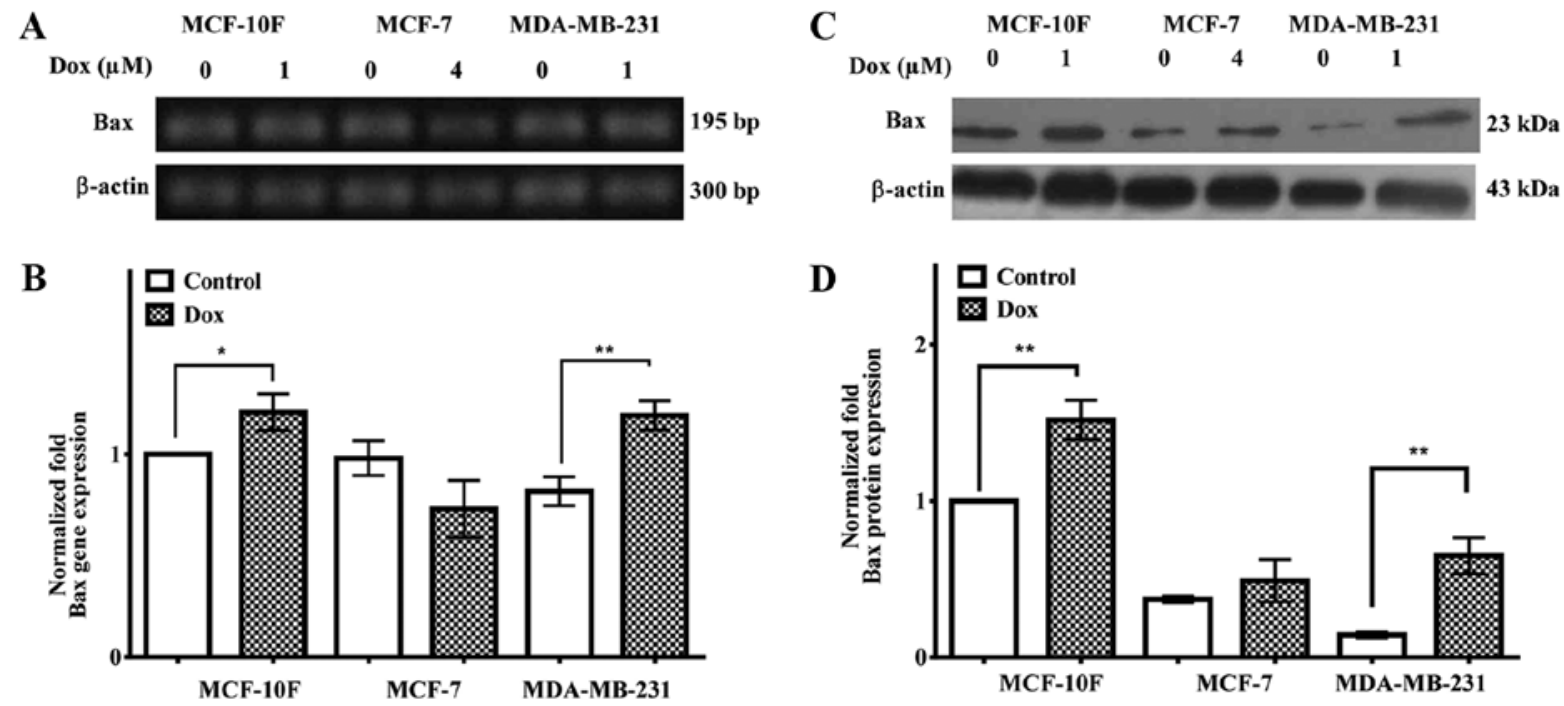

Figure 2. Effect of Dox on Bax gene expression (A) and quantified (B) in MCF-10F, MCF-7 and MDA-MB-231 cell lines by DDRT-PCR. Protein expression was determined by western blot analysis (C) and quantified (D). $\beta$-actin was used as housekeeping and control for loading, respectively. Band density of the specific gene and protein expression was analyzed with Adobe Photoshop program and the results were expressed as average density to $\beta$-actin. Graphs represent the normalized grade of luminescence to assess the gene and protein expression level of the cell lines. Bars represent the mean \pm SE of three independent experiments. ${ }^{*} \mathrm{P}<0.05,{ }^{* * *} \mathrm{P}<0.01$ vs. counterpart. $\mathrm{C}$, control cell line; Dox, doxorubicin.

On the other hand, MCF-7 cell line was dose-dependent after 24-h treatment.

Bax gene and protein expression. Bax gene and protein expression in MCF-10F, MCF-7 and MDA-MB-231 cell lines were determined with 1,4 and $1 \mu \mathrm{M}$ of Dox, respectively, for $48 \mathrm{~h}$. Results in Fig. 2A and quantified in B showed that Bax gene expression was upregulated in MCF-10F $(\mathrm{P}<0.05)$ and
MDA-MB-231 $(\mathrm{P}<0.05)$ cell lines but it was downregulated in the MCF-7 cell line. Fig. 2C and quantified in D indicated that Bax protein expression was upregulated in $\mathrm{MCF}-10 \mathrm{~F}$ and MDA-MB-231 cell lines $(\mathrm{P}<0.01)$ but MCF-7 cells did not show any significant increase.

Bcl-xL gene and Bcl-2 protein expression. Fig. 3A and quantified in $\mathrm{B}$ indicate that $\mathrm{Bcl}-\mathrm{xL}$ gene expression was 

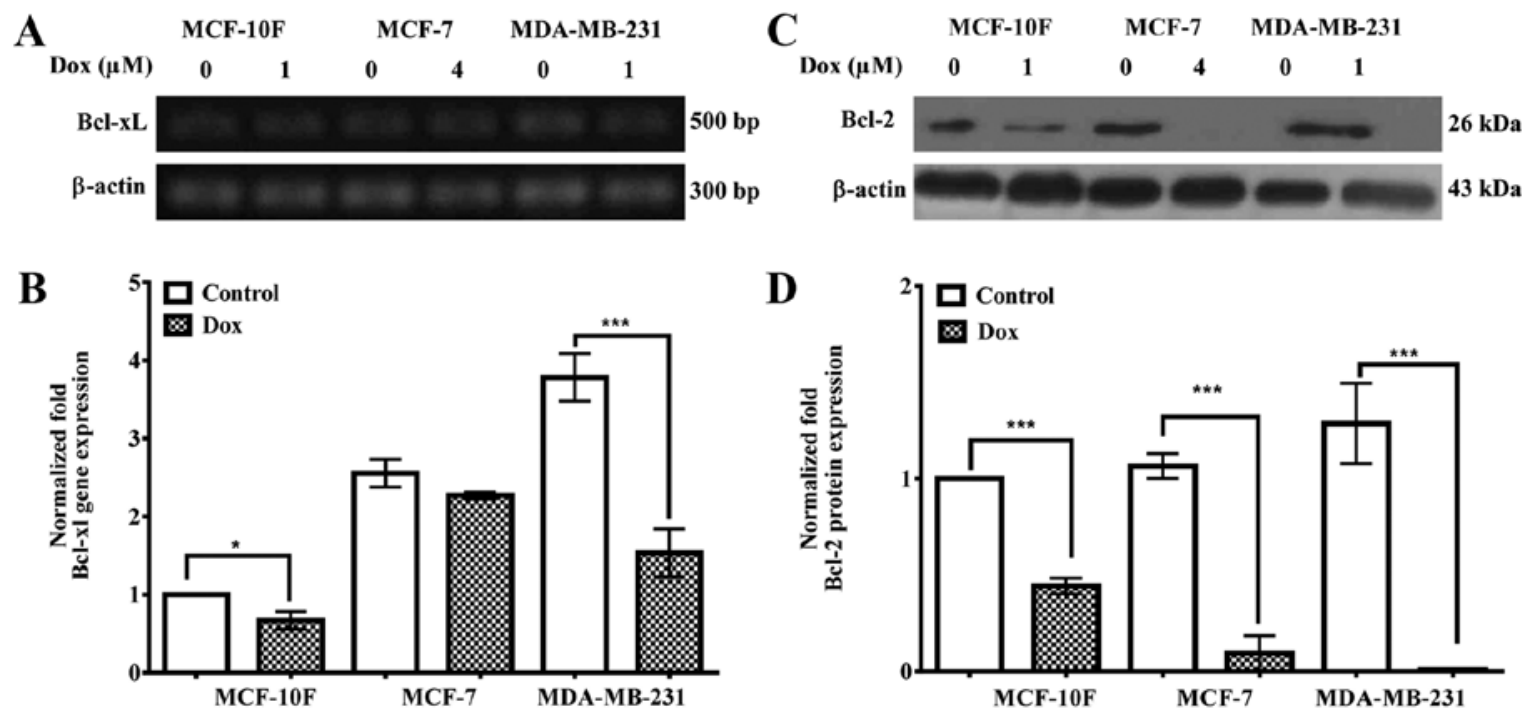

Figure 3. Effect of Dox on Bcl-xL gene expression (A) and quantified (B) in MCF-10F, MCF-7 and MDA-MB-231 cell lines by DDRT-PCR. Bcl-2 protein expression was determined by western blot analysis (C) and quantified (D). $\beta$-actin was used as housekeeping and control for loading, respectively. Band density of the specific gene and protein expression was analyzed with Adobe Photoshop program and the results were expressed as average density to $\beta$-actin. Graphs represent the normalized grade of luminescence to assess the gene and protein expression level of the cell lines. Bars represent the mean \pm SE of three independent experiments. ${ }^{* *} \mathrm{P}<0.01,{ }^{* * *} \mathrm{P}<0.001$ vs. counterpart. C, control cell line; Dox, doxorubicin.
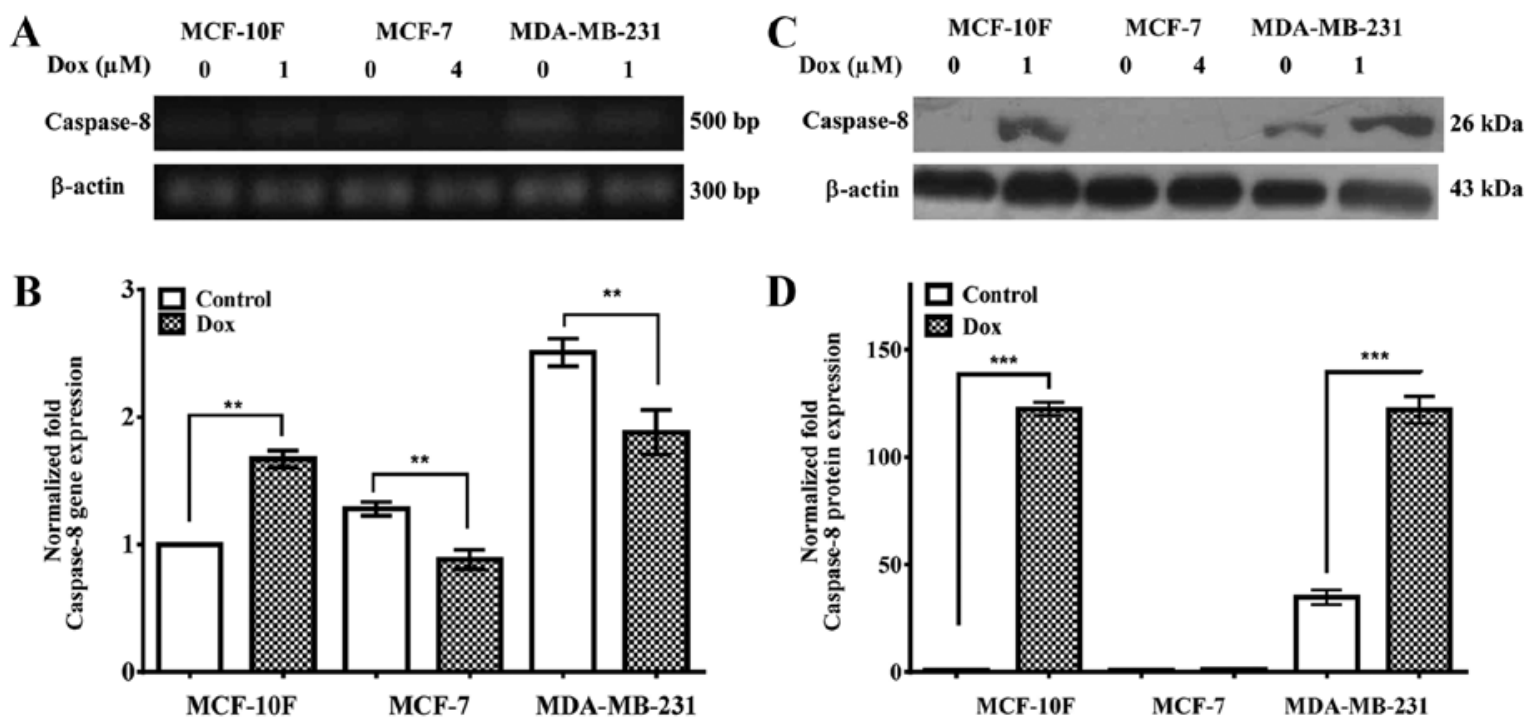

Figure 4. Effect of Dox on caspase-8 gene expression (A) and quantified (B) in MCF-10F, MCF-7 and MDA-MB-231 cell lines by DDRT-PCR. Protein expression was determined by western blot analysis (C) and quantified (D). $\beta$-actin was used as housekeeping and control for loading respectively. Band density of the specific gene and protein expression was analyzed with Adobe Photoshop program and the results were expressed as average density to $\beta$-actin. Graphs represent the normalized grade of luminescence to assess the gene and protein expression level of the cell lines. Bars represent the mean \pm SE of three independent experiments. ${ }^{* *} \mathrm{P}<0.01,{ }^{* * *} \mathrm{P}<0.001$ vs. counterpart. C, control cell line; Dox, doxorubicin.

significantly $(\mathrm{P}<0.05)$ downregulated in $\mathrm{MCF}-10 \mathrm{~F}$ and MDA-MB-231 $(\mathrm{P}<0.001)$ cells, but MCF-7 cells did not show significant decrease. Fig. 3C and quantified in D show that $\mathrm{Bcl}-2$ protein expression was significantly $(\mathrm{P}<0.001)$ decreased in all breast cancer cell lines (MCF-10F, MCF-7 and MDA-MB-231).

Caspase-8, caspase-9 and caspase- 3 gene and protein expression. Caspase-8, caspase- 9 and caspase- 3 gene and protein expression were studied in MCF-10F, MCF-7 and MDA-MB-231 cell lines. Fig. 4A and quantified in B show that caspase- 8 gene expression was upregulated in MCF-10F $(\mathrm{P}<0.01)$, but it was downregulated in MCF-7 $(\mathrm{P}<0.01)$ and MDA-MB-231 $(\mathrm{P}<0.01)$ cells. Fig. $4 \mathrm{C}$ and quantified in D indicated that caspase-8 protein expression was significantly $(\mathrm{P}<0.001)$ upregulated in MCF-10F and MDA-MB-231 cells when treated with Dox; though it was not detected in MCF-7 cells.

Fig. 5A and quantified in B indicated that caspase- 9 gene expression was higher in MDA-MB-231 cell line than in MCF-10F and MCF-7 cell lines in comparison with control cell lines. It also showed a decrease $(\mathrm{P}<0.05)$ in caspase-9 gene 

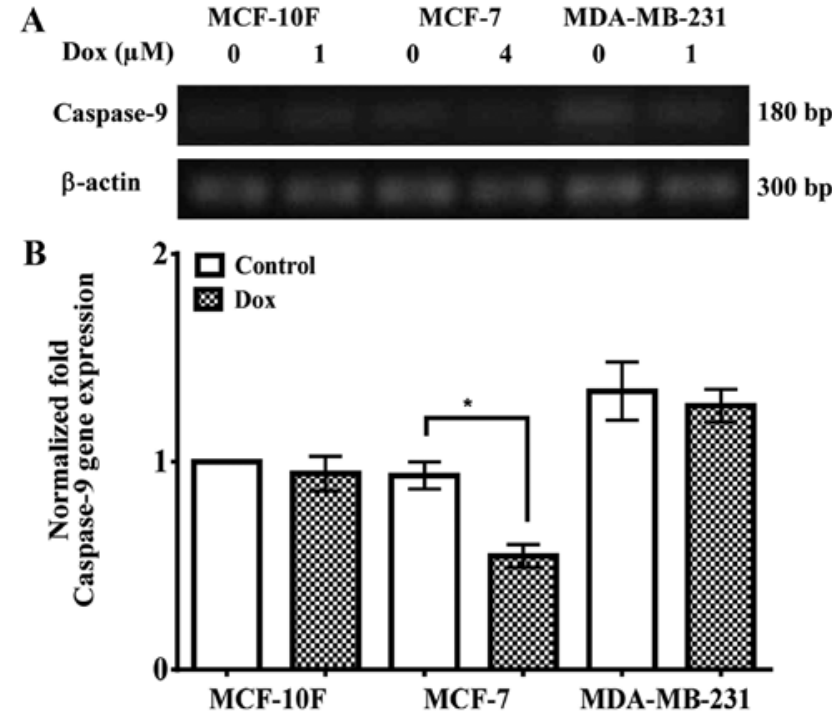

Figure 5. Effect of Dox on caspase-9 gene expression (A) and quantified (B), in MCF-10F, MCF-7 and MDA-MB-231 cell lines by DDRT-PCR. $\beta$-actin was used as housekeeping and control for loading respectively. Band density of the specific gene expression was analyzed with Adobe Photoshop program and the results were expressed as average density to $\beta$-actin. Graphs represent the normalized grade of luminescence to assess the gene expression level of the cell lines. Bars represent the mean $\pm \mathrm{SE}$ of three independent experiments. ${ }^{* *} \mathrm{P}<0.01$ vs. counterpart. C, control cell line; Dox, doxorubicin.

expression in MCF-7 cells in comparison to its counterparts. However, there was no difference in MCF-10F and MDA-MB231 cell lines.

Fig. 6A and quantified in $\mathrm{B}$, indicate that caspase- 3 gene expression was downregulated in MCF-7 $(\mathrm{P}<0.001)$ and MDA-MB-231 $(\mathrm{P}<0.001)$ cells. However, there was no difference in MCF-10F cell line. MCF-7 and MDA-MB-231 cells expressed higher level of caspase-3 gene expression than MCF-10F control cells. Results in Fig. 6C and quantified in D, show an increase in caspase-3 protein expression in MCF-10F $(\mathrm{P}<0.05)$ and MDA-MB-231 $(\mathrm{P}<0.01)$ cells in comparison to its counterparts. However, there was no significant difference in MCF-7 cells with its counterpart.

SOD2 gene and protein expression. SOD2 gene and protein expression were analyzed in Dox-treated cell lines. Results in Fig. 7A and quantified in $\mathrm{B}$, show an increase $(\mathrm{P}<0.01)$ in SOD2 gene expression in MCF-10F and MDA-MB-231 cells, whereas MCF-7 cells are downregulated $(\mathrm{P}<0.01)$. Fig. $7 \mathrm{C}$ and quantified in $\mathrm{D}$ showed a decrease in SOD2 protein expression significantly $(\mathrm{P}<0.05)$ decreased in MCF-10F and it was upregulated in MDA-MB-231 cells $(\mathrm{P}<0.001)$. MCF-7 cells did not express any significant difference.

$\mathrm{H}_{2} \mathrm{O}_{2}$ level in breast cancer cell lines exposed to Dox. The influence of Dox in $\mathrm{H}_{2} \mathrm{O}_{2}$ production was studied in MCF-10F, MCF-7 and MDA-MB-231 cell lines. Fig. 8 shows that untreated MCF-7 cell line expressed higher level of $\mathrm{H}_{2} \mathrm{O}_{2}$ than MCF-10F $(\mathrm{P}<0.05)$ control cells. MCF-10F cells did not express significant differences in the production of $\mathrm{H}_{2} \mathrm{O}_{2}$ when treated with Dox. MCF-7 $(\mathrm{P}<0.01)$ and MDA-MB-231 $(\mathrm{P}<0.01)$ cells showed higher concentrations of $\mathrm{H}_{2} \mathrm{O}_{2}$ production in comparison with its counterparts.

$N F-\kappa B$ gene and protein expression. Fig. 9A and quantified in $\mathrm{B}$, show increased NF- $\mathrm{KB}$ gene expression in MCF-10F $(\mathrm{P}<0.01)$ and MDA-MB-231 $(\mathrm{P}<0.05)$ but it was downregulated in MCF-7 $(\mathrm{P}<0.01)$. Results in Fig. $9 \mathrm{C}$ and quantified in $\mathrm{D}$, showed decreased NF- $\mathrm{KB}$ protein expression in MCF-10F $(\mathrm{P}<0.001)$, MCF-7 $(\mathrm{P}<0.01)$ and MDA-MB-231 $(\mathrm{P}<0.01)$ cells. Non-treated MCF-7 and MDA-MB-231 cell lines showed
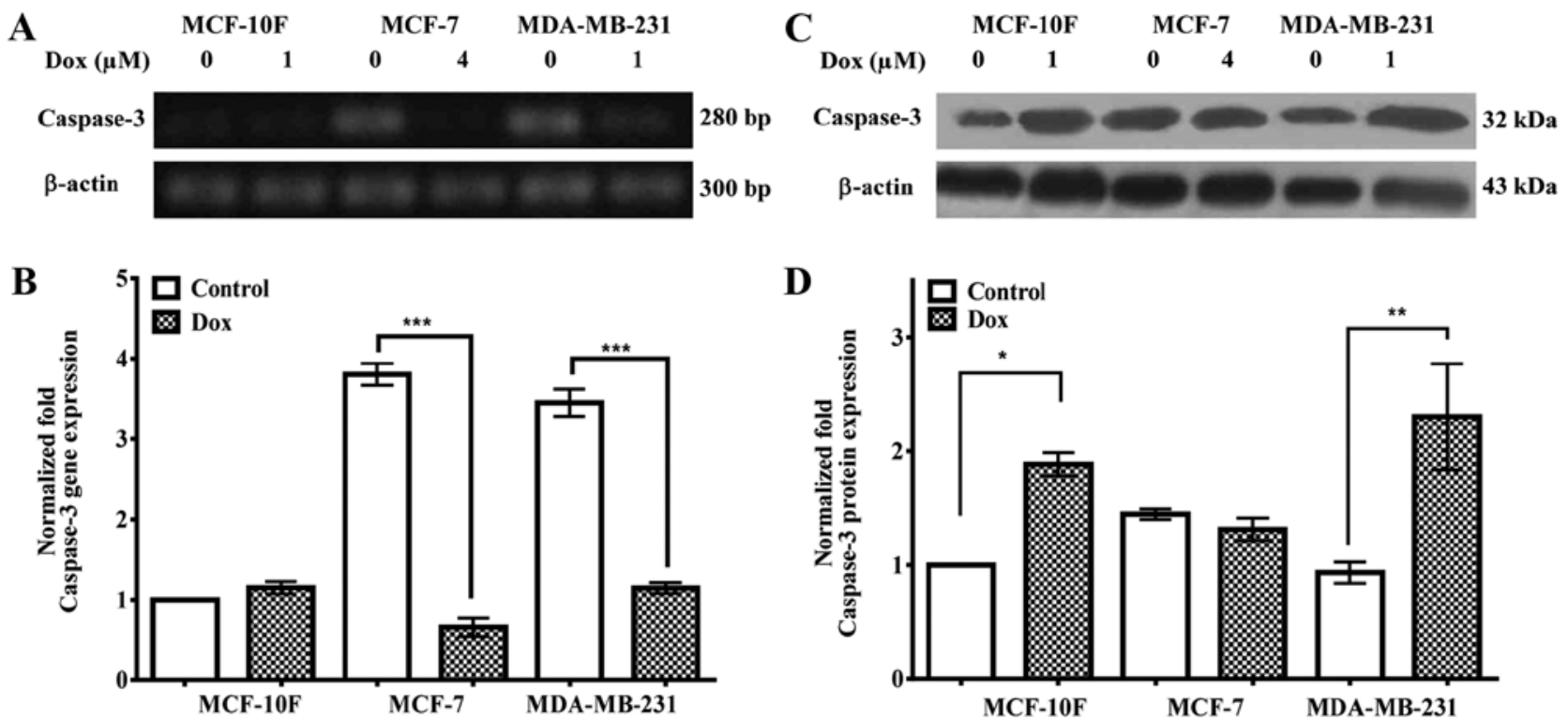

Figure 6. Effect of Dox on caspase-3 gene expression (A) and quantified (B) in MCF-10F, MCF-7 and MDA-MB-231 cell lines by DDRT-PCR. Protein expression was determined by western blot analysis (C) and quantified (D). $\beta$-actin was used as housekeeping and control for loading, respectively. Band density of the specific gene and protein expression was analyzed with Adobe Photoshop program and the results were expressed as average density to $\beta$-actin Graphs represent the normalized grade of luminescence to assess the gene and protein expression level of the cell lines. Bars represent the mean \pm SE of three independent experiments. ${ }^{*} \mathrm{P}<0.05,{ }^{* *} \mathrm{P}<0.01,{ }^{* * *} \mathrm{P}<0.001$ vs. counterpart. $\mathrm{C}$, control cell line; Dox, doxorubicin. 

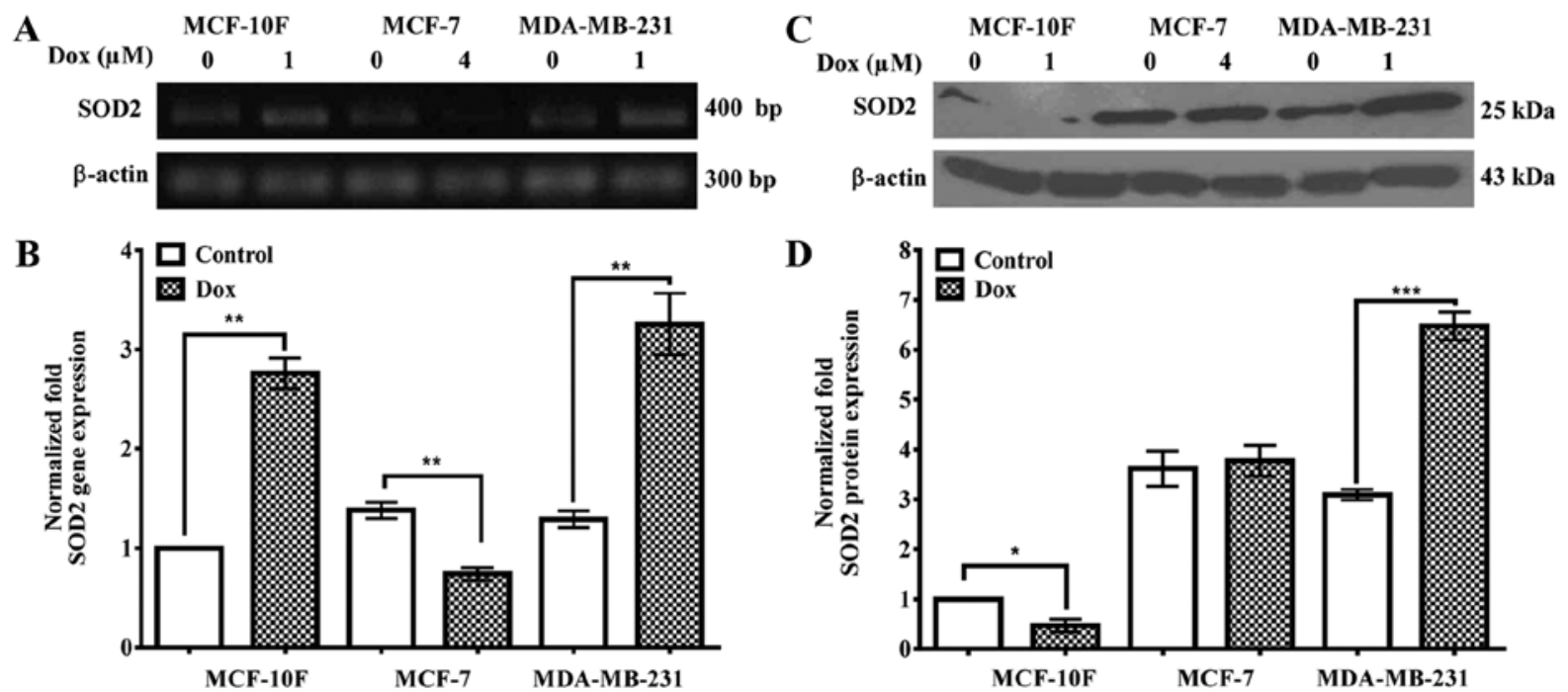

Figure 7. Effect of Dox on SOD2 gene expression (A) and quantified (B) in MCF-10F, MCF-7 and MDA-MB-231 cell lines by DDRT-PCR. Protein expression was determined by western blot analysis (C) and quantified (D). $\beta$-actin was used as housekeeping and control for loading, respectively. Band density of the specific gene and protein expression was analyzed with Adobe Photoshop program and the results were expressed as average density to $\beta$-actin. Graphs represent the normalized grade of luminescence to assess the gene and protein expression level of the cell lines. Bars represent the mean \pm SE of three independent experiments. ${ }^{*} \mathrm{P}<0.05,{ }^{* * *} \mathrm{P}<0.01,{ }^{* * *} \mathrm{P}<0.001$ vs. counterpart. C, control cell line; Dox, doxorubicin.

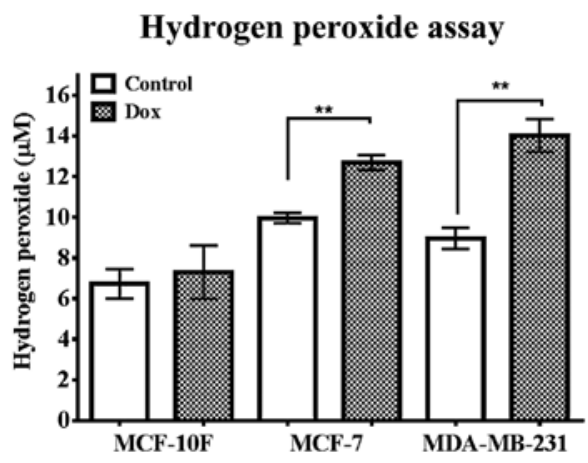

Figure 8. Hydrogen peroxide production assay. Amplex Red Hydrogen Peroxide assay kit was used. Peroxide hydrogen concentration was determined in MCF-10F, MCF-7 and MDA-MB-231 cell lines by using a quantitative colorimetric assay based on horseradish peroxide-catalyzed peroxide hydrogen oxidation of Amplex Red. The concentration $(\mu \mathrm{M})$ was calculated by measuring the absorbance at $560 \mathrm{~nm}$ using a microplate reader. Bars represent the mean $\pm \mathrm{SE}$ of three independent experiments. ${ }^{* *} \mathrm{P}<0.01$ vs. counterpart. C, control cell line; Dox, doxorubicin.

a lower protein expression in comparison to the $\mathrm{MCF}-10 \mathrm{~F}$ control cell line.

\section{Discussion}

Cytotoxic agents may induce apoptosis by initiating death signaling pathways in susceptible target cells. Apoptosis is induced by simultaneous or consequent activation of death receptor systems, disturbance in mitochondrial function, proteolytic processing of caspases, DNA damage and ROS damage (26). For evaluation of cytotoxicity induced by Dox the MTT assay was applied at 24 and $48 \mathrm{~h}$. Results demonstrated that MCF-10F, MCF-7 and MDA-MB-231 cell viability was clearly decreased in a dose-dependent manner. Thus, $\mathrm{IC}_{50}$ values were 1, 4 and $1 \mu \mathrm{M}$, respectively (Fig. 1) after 48-h treatment. The $\mathrm{IC}_{50}$ for MCF-7 has been established to fluctuated between 0.1 and $1.19 \mu \mathrm{M}(27-29)$ and it was found that MCF-7 cell line was more resistant than the MDA-MB-231 cell line (30-32).

The effect of Dox on gene and protein expression of Bax, Bcl-xL, Bcl-2, caspase-8, caspase-9 and caspase-3, all related to apoptosis as well as SOD2 to oxidative stress parallel to production of hydrogen peroxide were studied in MCF-10F, MCF-7 and MDA-MB-231 cell lines. Results indicated that Bax gene and protein expression was upregulated by Dox in MDA-MB-231, but not in MCF-7 cell line (33). Antitumoral drugs apply their effects controlling the expression levels of numerous members of the Bcl-2 family. Bcl-2 gene expression was downregulated in MCF-10F and MDA-MB-231, but not in MCF-7 cell line. Bcl-2 protein expression was decreased in the breast cancer cell lines MCF-10F, MCF-7 and MDA-MB-231. Members of the Bcl-2 family are main regulators of cell death or cell survival. The Bcl-2 family protein plays a significant role in apoptosis, either as apoptotic activators such as Bax or as apoptotic inhibitors such as Bcl-2 and Bcl-xL. Antiapoptotic Bcl-xL related gene expression should lead to an inhibition of apoptosis in MCF-7 cell line. Bcl-xL and Bcl-2 proteins are involved in apoptosis delay due to the interaction with cytochrome $c$ release $(11,34)$.

Apoptosis induced by Dox was evaluated by caspase- 8 , caspase- 9 and caspase- 3 gene and protein expression in three breast cancer cell lines. Caspase- 8 gene expression was downregulated in MCF-7 and MDA-MB-231 and its protein expression was upregulated in MCF-10F and MDA-MB-231 cell lines. However, it was not detected in MCF-7 cell line. It has been indicated that caspase- 8 accelerated apoptosis, presumably by recruitment of other caspases such as -9 and 3 - in B-lymphoid cells and breast cancer cells in a death, receptor-independent manner (35-37). It is also recruited by other apoptotic signals such as detachment-induced cell death but it is not essential for apoptosis induction (12). 

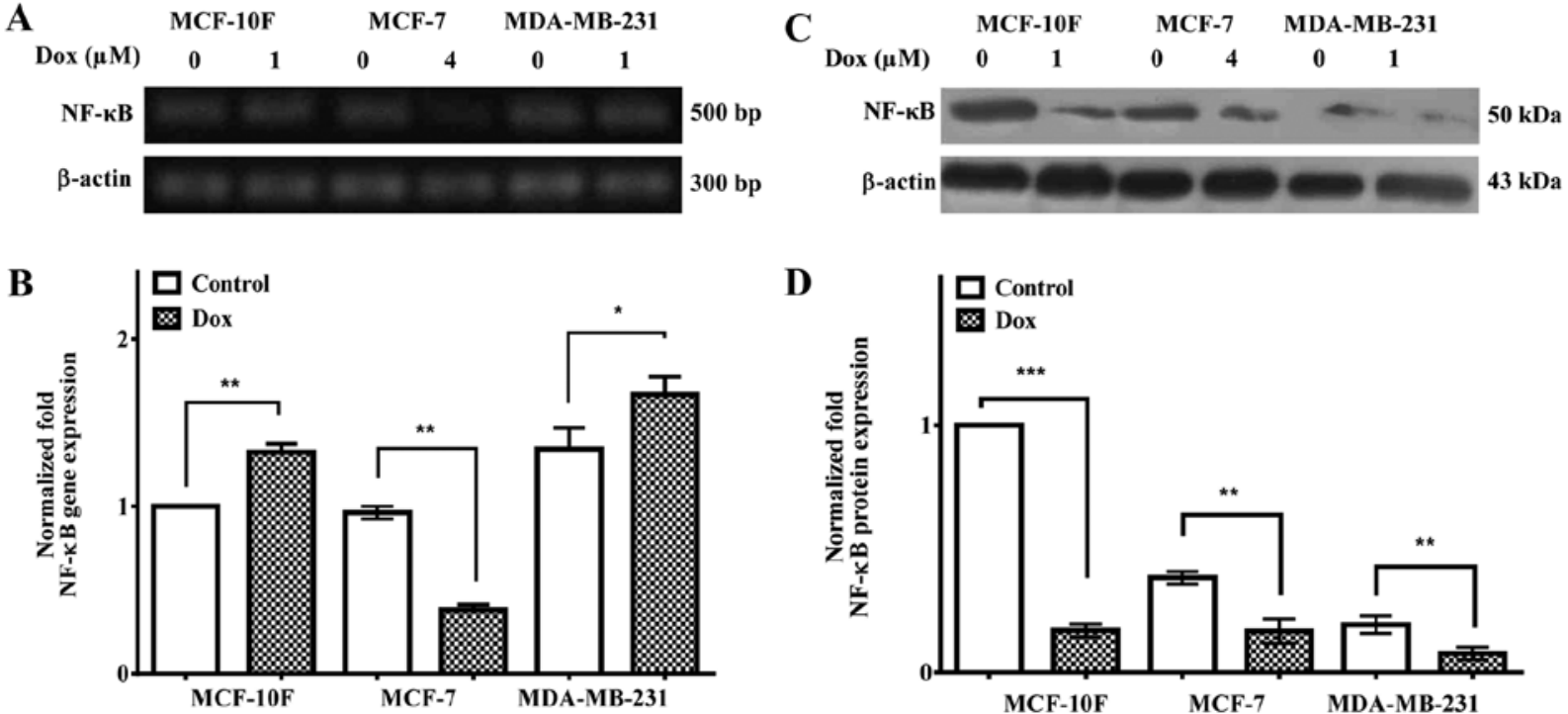

Figure 9. Effect of Dox on NF- $\mathrm{kB}$ gene expression (A) and quantified (B) in MCF-10F, MCF-7 and MDA-MB-231 cell lines by DDRT-PCR. Protein expression was determined by western blot analysis (C) and quantified (D). $\beta$-actin was used as housekeeping and control for loading, respectively. Band density of the specific gene and protein expression was analyzed with Adobe Photoshop program and the results were expressed as average density to $\beta$-actin. Graphs represent the normalized grade of luminescence to assess the gene and protein expression level of the cell lines. Bars represent the mean $\pm \mathrm{SE}$ of three independent experiments. ${ }^{*} \mathrm{P}<0.05,{ }^{* *} \mathrm{P}<0.01,{ }^{* * *} \mathrm{P}<0.001$ vs. counterpart. C, control cell line; Dox, doxorubicin.

The present study showed that caspase-9 gene expression was higher in MDA-MB-231 than in MCF-10F and MCF-7 cells. Caspase-9 gene expression decreased in MCF-7 cells in comparison to its counterpart when treated with Dox. Bcl-xL interacts with apoptosome to inhibit apoptosis by the caspase-9 formation (38). It has been demonstrated that MCF-7 and MDA-MB-231 cell lines initiated apoptosis by caspase-9 and its expression was increased with Dox-treatment $(39,40)$. In the present study Dox did not exert changes in gene expression in MDA-MB-231 cells.

Dox decreased caspase-3 gene expression in MCF-7 and MDA-MB-231 cell lines. However, the protein expression increased in MCF-10F and MDA-MB-231, but not in MCF-7 cell line. It was reported that MCF-7 cells did not express detectable levels of caspase-3 $(13,39)$, but contrary results also exist (41-43). McGee et al (44) suggested that caspase3 -independant apoptosis could be initiated by other effector caspases and then they may take over the role of caspase- 3 in mediating apoptosis in $\mathrm{MCF}-7$ cells.

Dox increased SOD2 gene expression in MDA-MB-231 cell line; however, it was decreased in $\mathrm{MCF}-7$ cell line. SOD2 protein expression was downregulated in MCF-10F cells and was upregulated in MDA-MB-231 cells. MCF-7 did not express significant difference. SOD2 enzyme has been demonstrated to play an important role in ROS damage by inhibiting cell proliferation (45). Cerutti et al (46) showed that SOD2 expression protected breast cancer cell lines from an aggressive phenotype, therefore, SOD2 overexpression is capable of inhibiting cell proliferation in vitro. Cancer cells contain elevated ROS levels, specifically $\mathrm{H}_{2} \mathrm{O}_{2}$ as a result of oncogenic transformation and a product of SOD2 activity excess $(22,47)$, and the present study is in agreement with these authors.

Dox increased $\mathrm{H}_{2} \mathrm{O}_{2}$ production in $\mathrm{MCF}-10 \mathrm{~F}, \mathrm{MCF}-7$ and MDA-MB-231 cell lines in comparison to its counterparts.
MCF-10F cell line did not express significant differences in the production of $\mathrm{H}_{2} \mathrm{O}_{2}$ when treated with Dox. Chua et al (48) found similar results. It was reported that high concentration of $\mathrm{H}_{2} \mathrm{O}_{2}$ induced an overexpression of specific oxidative related gene change such as $\mathrm{NF}-\kappa \mathrm{B} . \mathrm{H}_{2} \mathrm{O}_{2}$ production was related to the phosphorylation of I kappa B- $\alpha$ which was degraded and then activated NF- $\kappa \mathrm{B}$ (49-51).

Dox increased the NF- $\kappa \mathrm{B}$ gene expression in $\mathrm{MCF}-10 \mathrm{~F}$ and MDA-MB-231 but it decreased in MCF-7 cells. NF- $\kappa$ B protein expression level decreased in all cell lines when treated with Dox. It was confirmed that NF- $\kappa \mathrm{B}$ inhibition sensitized apoptosis when treated with Dox in various cancer cells e.g. breast cancer and pancreatic carcinoma (52). NF- $\kappa \mathrm{B}$ expression plays an anti-apoptotic role in various cancer cells such as breast cancer (53).

Dox decreased anti-apoptotic Bcl-2 protein expression and affected oxidative stress by increasing hydrogen peroxide production with simultaneously decrease $\mathrm{NF}-\kappa \mathrm{B}$ gene and protein expression in MCF-7, a tumorigenic triple-positive cell line. Results also indicated that Dox induced apoptosis by upregulating Bax, caspase- 8 and caspase-3 and downregulation of Bcl-2 protein expression. On the contrary, ROS damage decreased by increasing SOD2 gene and protein expression and hydrogen peroxide production with parallel $\mathrm{NF}-\kappa \mathrm{B}$ protein expression decrease in MDA-MB-231, tumorigenic triple-negative breast cancer cells. It can be concluded that Dox activated apoptosis by inducing proteolytic processing of Bcl-2 family, caspases and simultaneously decreased oxidative stress by influencing ROS damage in MCF-7 and MDA-MB-231 cells.

\section{Acknowledgements}

The technical support of Guiliana Rojas, Georgina Vargas Marchant and Leodán A. Crispin and helpful suggestions given by Richard Ponce-Cusi are greatly appreciated. 
The present study was supported by the Grant support FONDECYT\#1120006 (G.M.C) and MINEDUC-UTA (G.M.C).

\section{References}

1. Wu X, Liu X, Sengupta J, Bu Y, Yi F, Wang C, Shi Y, Zhu Y, Jiao $Q$ and Song F: Silencing of Bmi-1 gene by RNA interference enhances sensitivity to doxorubicin in breast cancer cells. Indian J Exp Biol 49: 105-112, 2011.

2. Sinha BK, Mimnaugh EG, Rajagopalan S and Myers CE: Adriamycin activation and oxygen free radical formation in human breast tumor cells: Protective role of glutathione peroxidase in adriamycin resistance. Cancer Res 49: 3844-3848, 1989.

3. Minotti G, Menna P, Salvatorelli E, Cairo G and Gianni L: Anthracyclines: Molecular advances and pharmacologic developments in antitumor activity and cardiotoxicity. Pharmacol Rev 56: 185-229, 2004

4. Jacobson MD, Weil M and Raff MC: Programmed cell death in animal development. Cell 88: 347-354, 1997.

5. Wong RS: Apoptosis in cancer: From pathogenesis to treatment. J Exp Clin Cancer Res 30: 87, 2011.

6. Chipuk JE, Moldoveanu T, Llambi F, Parsons MJ and Green DR: The BCL-2 family reunion. Mol Cell 37: 299-310, 2010.

7. Strobel T, Swanson L, Korsmeyer S and Cannistra SA: BAX enhances paclitaxel-induced apoptosis through a p53-independent pathway. Proc Natl Acad Sci USA 93: 14094-14099, 1996.

8. Kelly GL and Strasser A: The essential role of evasion from cell death in cancer. Adv Cancer Res 111: 39-96, 2011.

9. Chorna IV, Datsyuk LO and Stoika RS: Expression of Bax, $\mathrm{Bad}$ and $\mathrm{Bcl}-2$ proteins under $\mathrm{x}$-radiation effect towards human breast carcinoma MCF-7 cells and their doxorubicin-resistant derivatives. Exp Oncol 27: 196-201, 2005.

10. Lindsay J, Esposti MD and Gilmore AP: Bcl-2 proteins and mitochondria - specificity in membrane targeting for death. Biochim Biophys Acta 1813: 532-539, 2011.

11. Sharifi S, Barar J, Hejazi MS and Samadi N: Doxorubicin changes $\mathrm{Bax} / \mathrm{Bcl}-\mathrm{xL}$ ratio, caspase- 8 and 9 in breast cancer cells. Adv Pharm Bull 5: 351-359, 2015.

12. Wieder T, Essmann F, Prokop A, Schmelz K, Schulze-Osthoff K, Beyaert R, Dörken B and Daniel PT: Activation of caspase-8 in drug-induced apoptosis of B-lymphoid cells is independent of CD95/Fas receptor-ligand interaction and occurs downstream of caspase-3. Blood 97: 1378-1387, 2001.

13. Yang S, Zhou Q and Yang X: Caspase-3 status is a determinant of the differential responses to genistein between MDA-MB-231 and MCF-7 breast cancer cells. Biochim Biophys Acta 1773 903-911, 2007.

14. Porter AG and Jänicke RU: Emerging roles of caspase-3 in apoptosis. Cell Death Differ 6: 99-104, 1999.

15. Kruidering $M$ and Evan GI: Caspase- 8 in apoptosis: The beginning of 'the end'? IUBMB Life 50: 85-90, 2000.

16. Goffart S, von Kleist-Retzow JC and Wiesner RJ: Regulation of mitochondrial proliferation in the heart: Power-plant failure contributes to cardiac failure in hypertrophy. Cardiovasc Res 64: 198-207, 2004

17. Ridnour LA, Oberley TD and Oberley LW: Tumor suppressive effects of MnSOD overexpression may involve imbalance in peroxide generation versus peroxide removal. Antioxid Redox Signal 6: 501-512, 2004.

18. Vera-Ramirez L, Sanchez-Rovira P, Ramirez-Tortosa MC, Ramirez-Tortosa CL, Granados-Principal S, Lorente JA and Quiles JL: Free radicals in breast carcinogenesis, breast cancer progression and cancer stem cells. Biological bases to develop oxidative-based therapies. Crit Rev Oncol Hematol 80: 347-368, 2011.

19. Sosa V, Moliné T, Somoza R, Paciucci R, Kondoh $H$ and Leonart ME: Oxidative stress and cancer: An overview. Ageing Res Rev 12: 376-390, 2013

20. Miao L and St Clair DK: Regulation of superoxide dismutase genes: Implications in disease. Free Radic Biol Med 47: 344-356, 2009.

21. Kamarajugadda S, Cai Q, Chen H, Nayak S, Zhu J, He M, Jin Y, Zhang Y, Ai L, Martin SS, et al: Manganese superoxide dismutase promotes anoikis resistance and tumor metastasis. Cell Death Dis 4: e504, 2013.
22. Kattan Z, Minig V, Leroy P, Dauça M and Becuwe P: Role of manganese superoxide dismutase on growth and invasive properties of human estrogen-independent breast cancer cells. Breast Cancer Res Treat 108: 203-215, 2008.

23. Kiningham KK, Cardozo ZA, Cook C, Cole MP, Stewart JC, Tassone M, Coleman MC and Spitz DR: All-trans-retinoic acid induces manganese superoxide dismutase in human neuroblastoma through NF-kappaB. Free Radic Biol Med 44: 1610-1616, 2008.

24. Chen PM, Wu TC, Wang YC, Cheng YW, Sheu GT, Chen CY and Lee $\mathrm{H}$ : Activation of $\mathrm{NF}-\kappa \mathrm{B}$ by SOD2 promotes the aggressiveness of lung adenocarcinoma by modulating NKX2-1mediated IKK $\beta$ expression. Carcinogenesis 34: 2655-2663, 2013.

25. Mantovani A: Molecular pathways linking inflammation and cancer. Curr Mol Med 10: 369-373, 2010.

26. Fisher DE: Apoptosis in cancer therapy: Crossing the threshold. Cell 78: 539-542, 1994.

27. Lukyanova NY, Rusetskya NV, Tregubova NA and Chekhun VF: Molecular profile and cell cycle in MCF-7 cells resistant to cisplatin and doxorubicin. Exp Oncol 31: 87-91, 2009.

28. Taherian A and Mazoochi T: Different expression of extracellular signal-regulated kinases (ERK) $1 / 2$ and phospho-Erk proteins in MBA-MB-231 and MCF-7 cells after chemotherapy with doxorubicin or docetaxel. Iran J Basic Med Sci 15: 669-677, 2012.

29. Fornari FA, Randolph JK, Yalowich JC, Ritke MK and Gewirtz DA: Interference by doxorubicin with DNA unwinding in MCF-7 breast tumor cells. Mol Pharmacol 45: 649-656, 1994.

30. Schneiderman RS, Shmueli E, Kirson ED and Palti Y: TTFields alone and in combination with chemotherapeutic agents effectively reduce the viability of MDR cell sub-lines that over-express ABC transporters. BMC Cancer 10: 229, 2010.

31. Gupta P and Srivastava SK: Antitumor activity of phenethyl isothiocyanate in HER2-positive breast cancer models. BMC Med 10: 80, 2012.

32. Mahéo K, Vibet S, Steghens JP, Dartigeas C, Lehman M, Bougnoux P and Goré J: Differential sensitization of cancer cells to doxorubicin by DHA: A role for lipoperoxidation. Free Radic Biol Med 39: 742-751, 2005.

33. Green DR and Reed JC: Mitochondria and apoptosis. Science 281: 1309-1312, 1998 .

34. Tudor G, Aguilera A, Halverson DO, Laing ND and Sausville EA: Susceptibility to drug-induced apoptosis correlates with differential modulation of $\mathrm{Bad}, \mathrm{Bcl}-2$ and $\mathrm{Bcl}-\mathrm{xL}$ protein levels. Cell Death Differ 7: 574-586, 2000.

35. Varfolomeev EE, Schuchmann M, Luria V, Chiannilkulchai N, Beckmann JS, Mett IL, Rebrikov D, Brodianski VM, Kemper OC, Kollet O, et al: Targeted disruption of the mouse caspase 8 gene ablates cell death induction by the TNF receptors, Fas/Apol, and DR3 and is lethal prenatally. Immunity 9: 267-276, 1998.

36. Wesselborg S, Engels IH, Rossmann E, Los M and SchulzeOsthoff K: Anticancer drugs induce caspase-8/FLICE activation and apoptosis in the absence of CD95 receptor/ligand interaction. Blood 93: 3053-3063, 1999.

37. Liu WH and Chang LS: Fas/FasL-dependent and -independent activation of caspase- 8 in doxorubicin-treated human breast cancer MCF-7 cells: ADAM10 down-regulation activates Fas/ FasL signaling pathway. Int J Biochem Cell Biol Dec 43: $1708-1719,2011$

38. Hu Y, Benedict MA, Wu D, Inohara N and Núñez G: Bcl-XL interacts with Apaf-1 and inhibits Apaf-1-dependent caspase-9 activation. Proc Natl Acad Sci USA 95: 4386-4391, 1998.

39. Liang Y, Yan C and Schor NF: Apoptosis in the absence of Caspase 3. Oncogene 20: 6570-6578, 2001.

40. Cheah YH, Nordin FJ, Tee TT, Azimahtol HL, Abdullah NR and Ismail Z: Antiproliferative property and apoptotic effect of xanthorrhizol on MDA-MB-231 breast cancer cells. Anticancer Res 28 (6A): 3677-3689, 2008.

41. Cui Q, Yu JH, Wu JN, Tashiro S, Onodera S, Minami M and Ikejima T: P53-mediated cell cycle arrest and apoptosis through a caspase-3-independent, but caspase-9-dependent pathway in oridonin-treated MCF-7 human breast cancer cells. Acta Pharmacol Sin 28: 1057-1066, 2007.

42. Yang HL, Chen CS, Chang WH, Lu FJ, Lai YC, Chen CC, Hseu TH, Kuo CT and Hseu YC: Growth inhibition and induction of apoptosis in MCF-7 breast cancer cells by Antrodia camphorata. Cancer Lett 231: 215-227, 2006.

43. Chen JS, Konopleva M, Andreeff M, Multani AS, Pathak S and Mehta K: Drug-resistant breast carcinoma (MCF-7) cells are paradoxically sensitive to apoptosis. J Cell Physiol 200: 223-234, 2004. 
44. McGee MM, Hyland E, Campiani G, Ramunno A, Nacci V and Zisterer DM: Caspase-3 is not essential for DNA fragmentation in MCF-7 cells during apoptosis induced by the pyrrolo1,5-benzoxazepine, PBOX-6. FEBS Lett 515: 66-70, 2002.

45. Zhang Y, Zhang HM, Shi Y, Lustgarten M, Li Y, Qi W, Zhang BX and Van Remmen H: Loss of manganese superoxide dismutase leads to abnormal growth and signal transduction in mouse embryonic fibroblasts. Free Radic Biol Med 49: 1255-1262, 2010.

46. Cerutti P, Ghosh R, Oya Y and Amstad P: The role of the cellular antioxidant defense in oxidant carcinogenesis. Environ Health Perspect 102 (Suppl 10): 123-129, 1994.

47. Behrend L, Henderson G and Zwacka RM: Reactive oxygen species in oncogenic transformation. Biochem Soc Trans 31: 1441-1444, 2003.

48. Chua PJ, Yip GW and Bay BH: Cell cycle arrest induced by hydrogen peroxide is associated with modulation of oxidative stress related genes in breast cancer cells. Exp Biol Med (Maywood) 234: 1086-1094, 2009.

49. Takada Y, Mukhopadhyay A, Kundu GC, Mahabeleshwar GH, Singh S and Aggarwal BB: Hydrogen peroxide activates NF-kappa B through tyrosine phosphorylation of I kappa B alpha and serine phosphorylation of p65: evidence for the involvement of I kappa B alpha kinase and Syk protein-tyrosine kinase. J Biol Chem 278: 24233-24241, 2003.
50. Kretz-Remy C, Mehlen P, Mirault ME and Arrigo AP: Inhibition of I kappa B-alpha phosphorylation and degradation and subsequent NF-kappa B activation by glutathione peroxidase overexpression. J Cell Biol 133: 1083-1093, 1996.

51. Schreck R, Rieber P and Baeuerle PA: Reactive oxygen intermediates as apparently widely used messengers in the activation of the NF-kappa B transcription factor and HIV-1. EMBO J 10: 2247-2258, 1991

52. Arlt A, Vorndamm J, Breitenbroich M, Fölsch UR, Kalthoff H, Schmidt WE and Schäfer H: Inhibition of NF-kappa B sensitizes human pancreatic carcinoma cells to apoptosis induced by etoposide (VP16) or doxorubicin. Oncogene 20: 859-868, 2001

53. Wang S, Kotamraju S, Konorev E, Kalivendi S, Joseph J and Kalyanaraman B: Activation of nuclear factor-kappaB during doxorubicin-induced apoptosis in endothelial cells and myocytes is pro-apoptotic: The role of hydrogen peroxide. Biochem J 367: 729-740, 2002 